\title{
Bimbingan kelompok dalam pemahaman nilai empati untuk meningkatkan sikap prososial siswa
}

\author{
Ridho Rismi ${ }^{*}$, Neviyarni Neviyarni, Marjohan Marjohan, Afdal Afdal, Ifdil Ifdil \\ Universitas Negeri Padang, Indonesia
}

\begin{tabular}{l} 
Article Info \\
\hline Article history: \\
Received Jan $02^{\text {th }}, 2022$ \\
Revised Jan $30^{\text {th }}, 2022$ \\
Accepted Feb $03^{\text {rd }}, 2022$ \\
\hline
\end{tabular}

\section{Keyword:}

Bimbingan kelompok

Sikap prososial

Nilai empati

\section{Corresponding Author:}

Ridho Rismi,

Universitas Negeri padang

Email: ridhorismi.rr@gmail.com

\begin{abstract}
ABSTRAK
Sebagai makhluk sosial, siswa perlu untuk saling membantu dengan orang lain, salah satunya ia harus mampu menampilkan sikap prososial, agar terciptanya iklim yang baik dalam pergaulan dengan teman sebayanya. Sebagai upaya dalam peningkatan sikap prososial siswa, dalam penelitian kali ini akan digunakan salah satu layanan bimbingan dan konseling yaitu layanan bimbingan kelompok. Penelitian ini bertujuan menghasilkan model bimbingan kelompok yang efektif untuk mengembangkan sikap prososial siswa. Metodologi penelitian menggunakan desain eksperimen kuasi two-group pretest-posttest terhadap siswa SMA dengan mengambil populasi penelitian yaitu seluruh siswa dalam satu sekolah yang ditentukan dengan teknik purposive sampling. Pengumpulan data menggunakan instrumen prososial. Teknik analisis data menggunakan uji statistik Independent Sample T-Test dengan analisis data prososial siswa sebelum dan setelah mengikuti model bimbingan kelompok.
\end{abstract}

(C) 2022 The Authors. Published by IICET

This is an open access article under the CC BY-NC-SA license

(https://creativecommons.org/licenses/by-nc-sa/4.0

\section{Pendahuluan}

Manusia adalah makhluk sosial yang tidak dapat hidup sendiri, pada dasarnya manusia sebagai individu memerlukan pertolongan individu lain dalam kehidupannya. Individu memiliki keterikatan untuk dapat hidup bersama dengan individu lain dan saling berinteraksi antar yang lain, kebutuhan individu bukanlah kebutuhan yang hanya sebagai pelengkap untuk mengisi waktu luang. Siswa merupakan makhluk sosial yang tidak dapat hidup tanpa bantuan orang lain. Sebagai makhluk sosial, siswa perlu untuk saling membantu dengan orang lain, salah satunya ia harus mampu menampilkan sikap prososial, agar terciptanya iklim yang baik dalam pergaulan dengan teman sebayanya (Ulfa, 2019). Sikap merupakan suatu tindakan afeksi baik yang bersifat positif maupun negatif dalam hubungannya dengan objek-objek psikologis. Menurut Abu Ahmadi (Ulfa, 2019) sikap ialah suatu hal yang menentukan sifat, hakikat, baik perbuatan sekarang maupun perbuatan yang akan datang. Abu Ahmadi (Ulfa, 2019) mengungkapkan sikap seseorang tidak selamanya tetap, manakalanya ia dapat berkembang, mendapat pengaruh, baik dari dalam maupun dari luar yang bersifat positif dan mengesankan.

Sikap prososial dapat dilihat dari berbagai aspek, bertindak baik, tidak menyakiti, membantu, peduli dengan lingkungan dan lainnya harusditampilkan secara baik agar mempererat hubungan sosial. Prososial adalah salah satu bentuk perilaku yang muncul dalam kontak sosial (Robert Baron, 2005). Saat ini budaya gotong-royong dan tolong-menolong, serta solidaritas sosial pada masyarakat cenderung menurun, hal 
tersebut terjadi karena banyaknya individu yang hanya sibuk pada urusannya sendiri dan menghiraukan lingkungan sekitarnya (Yusuf Z., 2012).Sikap prososial hendaknya dapat ditingkatkan pada diri siswa, karena dapat mempengaruhi kepribadian siswa kedepannya sebagai makhluk sosial. Apabila sikap prososial siswa rendah, maka akan terbentuk sikap antisosial dan egois pada diri siswa.

Seiring perkembangan zaman semakin banyak muncul fenomena rendahnya perilaku prososial yang terungkap dari beberapa hasil penelitian berikut. Penelitian yang dilakukan oleh Niva (2016) pada 50 siswa kelas VIII SMP Bosowa International School Makassar menemukan bahwa sebanyak 34 siswa (68 \%) memiliki tingkat perilaku prososial yang rendah. Hasil observasi menunjukkan bahwa siswa malas membuang sampah yang sudah penuh, enggan membersihkan kamar tidur dan kamar mandi, tidak peduli terhadap teman yang tinggal bersama dalam satu asrama, terbentuk kelompokkelompok siswa berdasarkan daerah asal dan rendahnya perilaku bekerja sama antar siswa. Penelitian Saleem, Barlett, Anderson, dan Hawkins (2016) menyatakan bahwa remaja yang menunjukkan perilaku prososial yang rendah cenderung menunjukkan kecenderungan tanggung jawab sosial rendah, kecenderungan menyakiti orang lain, dan perilaku agresi lainnya yang tinggi terdapat kemungkinan bahwa remaja-remaja yang tidak mampu menunjukkan perilaku prososial dan disertai kemunculan perilaku-perilaku maladaptif menjadi remaja yang tidak diinginkan bahkan ditolak oleh kelompok sebayanya (Rahajeng, 2018). Hal ini diperkuat pula oleh studi penelitian sebelumnya oleh Hamidah (Isnandar, 2010) yang menemukan ditujuh daerah di Jawa Timur menunjukkan adanya indikasi penurunan kepedulian sosial dan kepekaan terhadap orang lain banyak terjadi pada remaja yang nampak lebih mementingkan diri sendiri dan keberhasilanya tanpa mempertimbangkan keadaan orang lain di sekitarnya. Hal ini menyebabkan remaja menjadi semakin individualis dan perilaku prososial yang dimiliki semakin pudar. Sedangkan pada penelitian lainya ditemukan bahwa ada hubungan positif yang sangat signifikan antara penalaran moral dengan perilaku prososial pada remaja. Rendahnya sikap prososial dapat membuat siswa menjadi seorang yang antisosial, maka dari itu sikap prososial di dalam diri siswa perlu ditingkatkan karena sangat bermanfaat bagi perkembangan sosial pada kehidupan selanjutnya.

Bimbingan dan konseling sebagai salah satu komponen sekolah yang memegang peranan penting dalam upaya perkembangan siswa terutama dalam sikap afektifnya. Bimbingan pada hakikatnya bertujuan memberikan bantuan kepada seluruh siswa agar tercapai dalam penyesuaian diri, perkembangan yang optimal, serta menjadi individu yang lebih mandiri (Melianasari, 2016). Salah satu upaya yang dapat meningkatkan sikap prososial siswa adalah dengan melaksanakan kegiatan bimbingan kelompok dengan pendekatan behavioristik dalam pengembangan pemahaman nilai empati.

Layanan bimbingan kelompok merupakan salah satu jenis layanan bimbingan dan konseling yang diberikan kepada sekelompok orang (klien) dengan memanfaatkan dinamika kelompok untuk memperoleh informasi dan pemahaman baru dari permasalahan (topik) yang dibahasnya. Menurut Romlah (Romlah, 2001) bahwa bimbingan kelompok adalah proses pemberia bantuan yang diberikan pada individu dalam situasi kelompok. Gazda (Prayitno, 2004) juga mengemukakan bahwa bimbingan kelompok di sekolah merupakan kegiatan pemberian informasi pada sekelompok siswa untuk membantu mereka menyusun rencana dan keputusan yang tepat. Dalam layanan kelompok, interaksi antar individu anggota kelompok merupakan suatu yang khas, yang tidak mungkin terjadi pada layanan perorangan. Dengan interaksi sosial yang intensif dan dinamis selama layanan tersebut berlangsung, diharapkan tujuantujuan layanan dapat tercapai secara lebih mantap (Prayitno, 2004). Pelaksanaan model bimbingan kelompok akan membahas dengan menanamkan atau memberikan informasi terkait pentingnya empati yang nanti akan berimplikasi kepada sikap prososial siswa.

Pada masa remaja, perubahan-perubahan yang terjadi demikian besarnya sehingga menimbulkan "kejutan" bagi remaja itu sendiri dan bagi lingkungannya. Perubahan yang terjadi pada masa remaja yaitu perubahan baik secara fisik, mental, intelektual dan sosial. Pada fase-fase remaja ini dapat menimbulkan masalah tertentu bagi remaja tersebut sehingga perlu adanya bimbingan dan penanganan untuk membantu mengenal kepribadiannya. Empati merupakan respon afektif yang berasal dari pemahaman kondisi emosional orang lain, perasaan yang sama dengan apa yang dirasakan orang lain. Empati adalah alat integral untuk mengetahui dan berhubungan dengan orang lain dan menambah kualitas hidup dan kekayaan interaksi sosial. Empati memiliki peran penting pada perkembangan pemahaman sosial dan perilaku sosial positif dan berfungsi sebagai fondasi hubungan dan menjadi dasar koping dengan stress dan penyelesaian konflik (Barr, 2009). Kepekaan sosial atau empati pada setiap orang bisa berbeda-beda. Empati biasanya tumbuh dari masa anakanak, mengikuti orang tua. Menurut Arsenio dan Lemerise (Constantinos, 2011) empati merupakan kemampuan untuk menghargai konsekuensi dari perilaku manusia terhadap perasaan orang lain dan berbagi serta berempati dengan perasaan orang lain. Orang yang enggan berbagi akan tumbuh menjadi pribadi yang individualistis dan egosentris. Sementara mereka yang sejak kecil sering dilibatkan untuk memahami kesulitan orang lain, biasanya akan lebih peka dan mudah tergerak hatinya untuk menolong sesama. Pendidikan empati 
sebagai inti dari pendidikan moral atau budi pekerti akan mampu menyentuh perkembangan perilaku remaja secara mendasar, apabila pendidikan empati tersebut ditanamkan pada anak sejak usia dini. Jika pendidikan empati tersebut diberikan pada anak setelah menginjak dewasa maka tidak akan begitu berpengaruh secara mendasar terhadap karakter dan pembentukan pribadi anak. Dasar kemampuan untuk berempati pada orang lain adalah adanya sikap hati terbuka, terbuka artinya mau mengerti perasaan orang lain dan mau dimengerti oleh orang lain.

Goleman (Goleman, 2000) menjelaskan bahwa dalam sikap empati yang terusmenerus diasah akan berpengaruh pada perkembangan moral. Seorang remaja yang memiliki empati tinggi akan lebih mudah untuk ikut merasakan apa yang dirasakan oleh orang lain dan tanggap terhadap lingkungan sosial sehingga mampu mengendalikan perilakunya (Rakhmat, 2001). Seseorang mengasah rasa empati dalam kehidupan yang dijalaninya sehingga dapat berbelas kasihan kepada orang lain yang membutuhkan bantuan. Misalkan saat menemui anak-anak yang kelaparan, seorang remaja yang memiliki empati tinggi akan memberi bantuan kepada anak tersebutdengan ikhlas. Dengan begitu, maka rasa empati akan semakin bertambah dan seorang remaja akan semakin peka apabila menemui contoh seperti yang dijumpainya. Sedangkan apabila seorang remaja memiliki rasa empati yang rendah maka hubungannya dengan orang lain akan gagal, artinya tidak mampu memahami perasaan orang lain dan tidak mampu merasakan posisi dan kondisi yang sedang dialami orang lain. Akibatnya akan sering terjadi salah persepsi dan konflik dengan orang lain.

\section{Method}

Desain untuk penelitian ini adalah literature review. Fraenkel (Fraenkel, 2012) mengemukakan bahwa kajian literatur adalah suatu kajian khazanah pustaka yang mendukung pada masalah khusus dalam penelitian yang sedang berlangsung

\section{Results and Discussions}

\section{Prososial}

Sikap merupakan suatu hal yang menentukan sifat, hakikat, baik perbuatan sekarang maupun perbuatan. Sikap suatu kesadaran individu yang menentukan perbuatan-perbuatan yang nyata ataupun yang mungkin akan terjadi di dalam kegiatan-kegiatan sosial. Abu Ahmadi (Ulfa, 2019) mengungkapkan sikap adalah suatu presdisposisi terhadap seseorang, ide atau objek yang berisi komponen-komponen cognitive, affective dan behavior. Sikap timbul karena adanya stimulus, terbentuknya suatu sikap itu banyak dipengaruhi oleh lingkungan sosial kebudayaan.

Sikap prososial merupakan salah satu bentuk sikap dalam kegiatan sosial yang dilakukan atau direncanakan untuk menolong orang lain tanpa mempedulikan motif-motif si penolong. Prososial lebih menuntut pada pengorbanan tinggi dari si pelaku dan bersifat suka rela atau lebih ditunjukkan untuk menguntungkan orang lain daripada untuk mendapatkan imbalan materi maupun sosial. Sarlito Wirawan Sarwono dan Eko (Sarlito, 2015) prososial didasari oleh beberapa faktor diantaranya adalah suasana hati, sifat, jenis kelamin, tempat tinggal, empati, dan pola asuh. Menurut Kartini (Ulfa, 2019) prososial merupakan suatu perilaku sosial yang dapat berpengaruh positif bagi seseorang, karena di dalamnya terdapat unsur-unsur kebersamaan, kerjasama, kooperatif dan altruisme.

Menurut Robert Baron dan Donn Byrne (Robert Baron, 2012) aspek-aspek prososial, 1) menolong orang lain yang kesulitan (helping a stranger distress), pengaruh kehadiran orang lain (bystander effect) membuat seseorang cenderung kurang memberikan bantuan pada orang asing yang mengalami kesulitan. Semakin banyak orang yang hadir, maka semakin kecil pula kemungkinan individu yang benar-benar memberikan pertolongan, 2) mengurangi suatu tindak pelanggaran (deterring a wrongdoer), berusaha untuk menciptakan keamanan dengan mengurangi pelanggaran dan adanya rasa tanggung jawab untuk memberikan bantuan kepada orang yang mengalami tindak pelanggaran. Komitmen utama terhadap tanggung jawabnya akan meningkatkan kemungkinan untuk bersikap prososial, 3) menahan godaan (reist temtation), individu seringkali dihadapkan pada pilihan antara melakukan apa yang diketahui dengan mempertahankan perilaku moral atau melakukan cara penyelesaian yang mudah melalui berbohong, berbuat curang, atau mencuri. Hal tersebut sangat menggoda individu untuk melanggar aturan yang ada agar memperoleh keuntungan dengan segera.

Prososial dapat ditingkatkan, menurut Bringham (Hudaniah, 2015) terdapat beberapa cara untuk meningkatkan prososial 1) penayangan model prososial, pembentukan prososial dapat dilakukan dengan sering memberikan stimulus mengenai perilaku-perilaku baik (membantu orang yang sedang mengalami kesulitan dan sebagainya). Semakin sering seseorang memperoleh stimulus, maka akan semakin mudah pula ia dapat melakukan imitasi (meniru) terhadap perilaku tersebut, 2) menciptakan suatu superordinate identity, 
setiap orang merupakan bagian dari beberapa kelompok. Ketika ia berada dalam kelompok tersebut, beberapa orang cenderung akan melakukan perbuatan yang menuntunnya agar dapat diterima oleh anggota kelompok tersebut, dan salah satu caranya yaitu dengan senantiasa berbuat baik untuk orang lain serta menghindarkan diri dari perbuatan yang buruk, 3) menekankan perhatian terhadap norma-norma prososial, pembelajaran mengenai norma adalah tanggung jawab sosial, yang dapat ditanamkan oleh Orangtua, Guru, serta media masa. Apabila hal tersebut tidak ditanamkan, maka akan membentuk sikap anti sosial atau tidak peduli pada lingkungan sekitar dan dapat mempengaruhi perkembangan psikologis dan sosial seseorang.

\section{Bimbingan Kelompok}

Bimbingan dan konseling merupakan upaya pemberian bantuan yang bersifat pencegahan maupun pengembangan, untuk membantu individu mengembangkan potensi diri secara optimal. Bimbingan kelompok merupakan strategi untuk membantu individu mengembangkan potensi yang dimiliki. Proses pemberian bantuan diberikan agar setiap individu mampu mengatasi permasalahan yang dihadapi. Kegiatan bimbingan dilakukan dalam kelompok kecil maupun besar dan dipimpin oleh satu konselor.

Winkel dan Hastuti (Winkel, 2012) menjelaskan bimbingan kelompok dilaksanakan apabila jumlah orang yang diberikan bantuan lebih dari satu orang. Kolompok dapat dibentuk menjadi kelompok kecil, agak besar, dan sangat besar. Menurut Natawidjaya (1987), bimbingan kelompok merupakan suatu sistem pemberian layanan bantuan yang sangat baik untuk membantu mengembangkan kemampuan pribadi, pencegahan dan menanganai knflik.

Menurut Rusmana (Warni, 2020) bimbingan kelompok dapat didefinisikan sebagai suatu proses pemberian bantuan kepada individu melalui suasana kelompok yang memungkinkan setiap anggota untuk belajar berpartisipasi aktif dan berbagi pengalaman dalam upaya pengembangan wawasan, sikap dan keterampilan yang diberikan dalam upaya mencegah timbulnya masalah dan dalam upaya pengembangan pribadi. Dari berbagai defenisi yang diungkapkan para ahli dapat disimpulkan, bimbingan kelompok merupakan suatu proses pemberian bantuan yang diberikan oleh seorang konselor kepada konseli yang berbentuk dinamika kelompok yang memungkinkan setiap anggota kelompok berpartisipasi aktif dan berbagi pengalaman dalam upaya ilmu dan memperluas wawasan, sikap dan keterampilan yang diperlukan dalam upaya pengemabangan pribadi.

Tujuan bimbingan menurut Tohirin (Tohirin, 2013) secara umum untuk meningkatkan kemampuan bersosialisai, terutama kemampuan komunikasi siswa. Secara khusus layanan bimbingan kelompok memiliki tujuan untuk mendorong, dan mengembangkan perasaan, pikiran, persepsi, wawasan, serta tingkah laku yang afektif yaitu meningkatkan kemampuan berkomunikasi baik verbal maupun nonverbal.

Dinkmeyer \& Muro (Amarta, 2021) menjelaskan tujuan bimbingan kelompok, 1) membantu setiap anggota kolompok mengetahu dan memahami dirinya untuk membantu proses menemukan identitas, 2) dengan memahami diri sendiri, maka siswa diharapkan akan semakin mampu mengembangkan penerimaan diri dan merasa berharga sebagai pribadi, 3)membantu mengembangkan keterampilan sosial dan kecakapan antar pribadi, sehingga siswa mampu melaksanakan tugas perkembangan dalam kehidupan sosial-pribadi, 4) menumbuhkembangkan kecakapanmengarahkan diri, memecahkan masalah, dan mentranfer kecakapan untuk digunkan dalam kehidupan sosial sehari-hari, 5) membantu mengembangkan kepekaan terhadapat kebutuhan orang lain, sihingga menyadari dan bertangung jawab terhadap tingkah laku kepada orang lain. Belajar mengidentifikasi perasaan orang-orang yang berarti dalam hidupnya (singnificant others), sehingga mampu menunjukan kecapan yang lebih baik untuk bersikap empati, 6) membantu siswa belajar bagaimana menjadi pendengar yang empati, yang mendengar bukan saja yang diucapkan, tetapi dapat mendengar perasaan-perasaan yang mengikuti ucapan orang lain, 7) membantu sisiwa untuk dapat memberi makna terhadap sesuatu sesuai dengan keyakinan dan pemikiran yang dimiliki, 8) membantu setiap anggota kelompok untuk dapat merumuskan tujuan-tujuan tertentu yang akan diwujudkan secara konkrit.Mengacu pada pendapat Gladding (Gladding, 2012) tahap pelaksanaan bimbingan bimbingan kolompok dibagi menjadi empat tahap. Empat tahap bimbingan kelompok, 1) tahap awal (the beginning a stage), 2) tahap transisi (the transition stage in a group), 3) tahap kerja (the working stage in a group) dan, 4) teknik terminasi (termination of a group)

\section{Empati}

Empati merupakan respon afektif yang berasal dari pemahaman kondisi emosional orang lain, perasaan yang sama dengan apa yang dirasakan orang lain. Empati adalah alat integral untuk mengetahui dan berhubungan dengan orang lain dan menambah kualitas hidup dan kekayaan interaksi sosial. Menurut Barr Higgins (Wewengkang, 2016) empati memiliki peran penting pada perkembangan pemahaman sosial dan perilaku sosial positif dan berfungsi sebagai fondasi hubungan dan menjadi dasar koping dengan stress dan penyelesaian konflik. Kepekaan sosial atau empati pada setiap orang bisa berbeda-beda. Empati biasanya 
tumbuh dari masa anak-anak, mengikuti orang tua. Menurut Arsenio dan Lemerise (Mashar, 2017), empati merupakan kemampuan untuk menghargai konsekuensi dari perilaku manusia terhadap perasaan orang lain dan berbagi serta berempati dengan perasaan orang lain. Orang yang enggan berbagi akan tumbuh menjadi pribadi yang individualistis dan egosentris. Sementara mereka yang sejak kecil sering dilibatkan untuk memahami kesulitan orang lain, biasanya akan lebih peka dan mudah tergerak hatinya untuk menolong sesama. Pendidikan empati sebagai inti dari pendidikan moral atau budi pekerti akan mampu menyentuh perkembangan perilaku remaja secara mendasar, apabila pendidikan empati tersebut ditanamkan pada anak sejak usia dini. Jika pendidikan empati tersebut diberikan pada anak setelah menginjak dewasa maka tidak akan begitu berpengaruh secara mendasar terhadap karakter dan pembentukan pribadi anak. Dasar kemampuan untuk berempati pada orang lain adalah adanya sikap hati terbuka, terbuka artinya mau mengerti perasaan orang lain dan mau dimengerti oleh orang lain.

Goleman (Goleman, 2015) menjelaskan bahwa dalam sikap empati yang terus-menerus diasah akan berpengaruh pada perkembangan moral. Seseorang mengasah rasa empati dalam kehidupan yang dijalaninya sehingga dapat berbelas kasihan kepada orang lain yang membutuhkan bantuan. Misalkan saat menemui anak-anak yang kelaparan, seorang remaja yang memiliki empati tinggi akan memberi bantuan kepada anak tersebutdengan ikhlas. Dengan begitu, maka rasa empati akan semakin bertambah dan seorang remaja akan semakin peka apabila menemui contoh seperti yang dijumpainya. Sedangkan apabila seorang remaja memiliki rasa empati yang rendah maka hubungannya dengan orang lain akan gagal, artinya tidak mampu memahami perasaan orang lain dan tidak mampu merasakan posisi dan kondisi yang sedang dialami orang lain. Akibatnya akan sering terjadi salah persepsi dan konflik dengan orang lain. Contohnya seorang remaja tidak mempunyai rasa belas kasihan bahkan terkesan tidak peduli ketika menyaksikan sesamanya mengalami kesusahan. Seorang remaja tidak akan merasa terpanggil untuk memberikan bantuan kepada sesama.

\section{Simpulan}

Individu memiliki keterikatan untuk dapat hidup bersama dengan individu lain dan saling berinteraksi antar yang lain, kebutuhan individu bukanlah kebutuhan yang hanya sebagai pelengkap untuk mengisi waktu luang. Rendahnya sikap prososial dapat membuat siswa menjadi seorang yang antisosial, maka dari itu sikap prososial di dalam diri siswa perlu ditingkatkan karena sangat bermanfaat bagi perkembangan sosial pada kehidupan selanjutnya. Layanan bimbingan kelompok merupakan salah satu jenis layanan bimbingan dan konseling yang diberikan kepada sekelompok orang (klien) dengan memanfaatkan dinamika kelompok untuk memperoleh informasi dan pemahaman baru dari permasalahan (topik) yang dibahasnya. Empati merupakan respon afektif yang berasal dari pemahaman kondisi emosional orang lain, perasaan yang sama dengan apa yang dirasakan orang lain. Empati memiliki peran penting pada perkembangan pemahaman sosial dan perilaku sosial positif. Seorang remaja yang memiliki empati tinggi akan lebih mudah untuk ikut merasakan apa yang dirasakan oleh orang lain. Sedangkan apabila seorang remaja memiliki rasa empati yang rendah maka hubungannya dengan orang lain akan gagal, artinya tidak mampu memahami perasaan orang lain dan tidak mampu merasakan posisi dan kondisi yang sedang dialami orang lain.

\section{References}

Amarta, D. \& Pravesti, C. (2021). Keefektifan Biblioedukasi untuk Meningkatkan Efikasi Diri Akademik Siswa VII-A SMPN 3 Krian. Jurnal Konseling Indonesia Vol. 6 No. 2

Constantinos. (2011). The Relationship Between Bullying, Victimization, Trait Emotional Intelligence, Self Efficacy and Empathy Among Preadolescents. Soc Psychol Educ, 15:41-58.

Creswell, J. W. (2015). Educational Research: Planning, Conducting, and Evaluating Quantitative and Qualitative Research. Pearson.

Fraenkel, Jack. (2012). How to Design and Evaluate Research in Education $8^{\text {th }}$ Edition. Boston: McGraw-Hill Higher Education

Gladding. (2012). Group Work: A Counselling Specialty (Sixth). Pearson Prentice Hall.

Goleman, D. (2015). Working with Emotional Intelligence (terjemahan). PT Gramedia Pustaka Utama.

Hudaniah, T. D. \&. (2015). Psikologi Sosial. Universitas Muhammadiyah Malang Press.

Mashar, R \& Sulistiyowati. (2017). Story in Reducing Childhood Aggression Behavior. Conference: International Conference PIAUD. Pontianak: IAIN Pontianak

Melianasari, D. (2016). Penerapan Layanan Bimbingan Kelompok Melalui Teknik Permainan Simulasi dan Untuk Meningkatkan Kecerdasan Emosi Siswa. Pedagogia, 14(2), 311-317. https://doi.org/10.17509/pedagogia.v14i2.3880 
Putu Nopi Sayondari, Ni Nengah Madri Antari, N. D. (2014). Penerapan Bimbingan Kelompok dengan Teknik Diskusi Kelompok untuk Meningkatkan Rasa Percaya Diri Siswa Kelas VIII E SMP Negeri 3 Singaraja Tahun Pelajaran 2013/2014. Bimbingan Dan Konseling, 2 No. 1.

Rahajeng, W. (2018). Perilaku Prososial sebagai Prediktor Status Teman Sebaya pada Remaja. Psikologi Teori Dan Terapan, 8(2): 124-.

Robert Baron, D. B. (2012). Psikologi Sosial. Jilid 2. Alih Bahasa: Ratna Juwita (Kesepuluh). Erlangga.

Sarlito Wirawan Sarwono, E. M. (2015). Psikologi Sosial. Salemba Humanika.

Sugiyono. (2013). Metode Penelitian Pendidikan (Pendekatan Kuantitatif, Kualitatif dan R\&D). Alfabeta.

Tohirin. (2013). Bimbingan Konseling di Sekolah dan Madrasah (Berbasis Integrasi). Jakarta: Rajawali Press

Ulfa, Neviyarni, Indah. (2019). Efektivitas Teknik Sosiodrama Setting Kelompok untuk Meningkatkan Sikap Prososial Siswa SMA Adabiah 2 Padang. Jurnal Neo Konseling, Vol 1, No. 4

Warni, S., \& Firman, F. (2020). Efektifitas Layanan Bimbingan Kelompok dalam Peningkatan Self Regulate Learning Siswa Pengguna Game Online. Jurnal Neo Konseling, Vol 2, No. 3

Wewengkang, D. B. P. (2016). Studi Fenomenologi Konteks Budaya Jawa dan Pengaruh Islam: Situasi Psikologis Keluarga dalam Membangun Empati pada Remaja. Jurnal Indigenous Vol. 1 No. 1 1-11

Winkel, W. S., \& Hastuti, S. (2012). Bimbingan dan Konseling di Institut Pendidikan. Media Abadi.

Yusuf Z., L. A. (2012). The Difference Between Prosocial Tendency Regular Classes and Special SMAN 1 and SMAN 3 Semarang. Psikologi, (1), 120-1. 